\title{
Strategi Dialektika Relasional Pasangan Suami Isteri di Masa Pandemi Covid-19
}

\author{
Elisha Kristiani Putri ${ }^{1}$, Fanny Lesmana ${ }^{2 *}$, Desi Yoanita ${ }^{3}$ \\ 123 Universitas Kristen Petra \\ Alamat: Jl. Siwalankerto 121-131 Surabaya (60236), Indonesia \\ Email: putri.elisha1998@gmail.com
}

\section{Relational Dialectical Strategy of Married Couples during the Covid-19 Pandemic}

\begin{abstract}
This research was conducted to determine the relational dialectics strategy of married couples facing the Covid-19 pandemic. There were two couples as interviewees, the first spouse experienced work from home (WFH). The second one whose husband has worked from office (WFO). This research uses a qualitative approach with a case study method. Based on the findings of the data obtained, it shows that the WFH pair is more directed at autonomy, stability and closedness, while the WFO pair refers to connection, change and openness. From the research conducted, researchers can find five things that can cause dialectical tension for couples during a pandemic. First, the closeness of the partner depends on the age and character of the child. Second, work determines the interaction of partners during a pandemic. Third, family backgrounds shape relationships in the family. Fourth, character and personal preferences shape responses in relationships. Finally, adaptations and communication alternatives facing the pandemic. Then the strategies that are mostly used by both partners are segmentation and integration. It is also seen how communication is an important (key) in forming an agreement by adjusting between partners.
\end{abstract}

Keywords: couples; covid-19; marital communication; relational dialectics

\section{ABSTRAK}

Penelitian ini dilakukan untuk mengetahui strategi dialektika relasional pasangan suami isteri di masa pandemi Covid-19. Terdapat dua pasangan sebagai narasumber, pasangan pertama mengalami work from home (WFH) dan pasangan kedua yang suaminya telah work from office (WFO). Penelitian ini menggunakan pendekatan kualitatif dengan metode studi kasus dan teori dialektika relasional. Berdasarkan temuan data yang diperoleh menunjukkan pasangan WFH lebih mengarah pada autonomy, stability dan closedness sedangkan pasangan WFO merujuk pada connection, change dan openness. Ditemukan lima hal yang dapat menimbulkan tegangan dialektika bagi pasangan di masa pandemi. Pertama, kedekatan pasangan dipengaruhi oleh usia dan karakter anak. Kedua, pekerjaan menentukan interaksi pasangan di masa pandemi. Ketiga, latar belakang keluarga membentuk hubungan dalam keluarga. Keempat, karakter dan preferensi pribadi membentuk respon dalam hubungan. Terakhir, adaptasi dan alternatif komunikasi dalam menghadapi masa pandemi. Mayoritas strategi yang digunakan kedua pasangan adalah segmentasi dan integrasi. Dapat disimpulkan komunikasi adalah kunci dalam membentuk kesepakatan dengan menyesuaikan diri antar pasangan.

Kata kunci: covid-19; dialektika relasional; komunikasi pernikahan; pasutri 


\section{LATAR BELAKANG}

Pandemi Covid-19 telah menjadi sumber berbagai kebijakan seperti work from home, social atau physical distancing, PSBB (Pembatasan Sosial Berskala Besar) hingga New Normal. Menurut Ketua Departemen IImu Keluarga dan Konsumen, Institut Pertanian Bogor, Dr Tin Herawati, wabah corona virus telah mempengaruhi berbagai jenjang masyarakat termasuk unit sosial terkecil yaitu keluarga. la juga menyatakan bahwa Covid-19 yang mengguncang berbagai sektor dari ekonomi, sosial, pendidikan, kesehatan dan sebagainya menjadi sumber dari topik konflik keluarga (Herawati, 2020). Masalah keuangan, pekerjaan, komunikasi, hubungan, dan lain-lain sangat mempengaruhi kondisi keluarga. Akibatnya timbul respon tak terkendali seperti konflik hingga kekerasan dalam rumah tangga (Nursastri, 2020).

Kebijakan-kebijakan yang ada akibat pandemi menyebabkan keluarga konsisten bertemu di rumah selama hampir 24 jam. "Menurut hasil survei online oleh Badan Kependudukan dan Keluarga Berencana Nasional (BKKBN) terhadap lebih dari 20.000 keluarga ditemukan 95\% keluarga dilaporkan stres akibat pandemi dan pembatasan sosial" (Sudiana, 2020). Akibatnya mempengaruhi komunikasi antar pasangan di mana semakin sering bertemu maka semakin sering terjadi gesekan berupa dorongan dan tarikan. Gesekan itu disebut juga sebagai kontradiksi pada kehidupan sehari-hari yang terus terjadi dalam hubungan pasangan (Tim, 2020).

Olson (2008) mengatakan bahwa komunikasi berfungsi sebagai minyak yang menghaluskan gesekan antara pasangan dan anggota keluarga. Schrodt (2005) menekankan pentingnya komunikasi dalam mempengaruhi cara keluarga mengelola dimensi kohesi dan fleksibilitas. la berkata "Keterampilan komunikasi yang positif, termasuk kejelasan, empati, dan pemecahan masalah yang efektif, diyakini dapat memfasilitasi tingkat kohesi keluarga yang sehat dan fleksibilitas. Sebaliknya kurangnya keterampilan komunikasi dapat menghambat kemampuan adaptasi sistem keluarga" (Galvin et al., 2018)

Pengungkapan maupun menjaga privasi bekerja bersamaan dalam membentuk keterikatan dengan anggota keluarga maupun menyediakan ruangan independensi. Sering kali pilihan tersebut tidak mudah sehingga membuat keputusan yang tepat menjadi samar-samar (Petronio, 2010). Hal tersebut akhirnya menimbulkan konflik batin pada pribadi pasangan yang dijelaskan dalam teori dialektika relasional.

Penelitian mengenai Dialektika Konflik juga dilakukan oleh Dewi Irawati pada tahun 2013 merupakan lulusan Universitas Diponegoro dengan judul "Memahami Dialektika Konflik dan Pengalaman Komunikasi Pasangan Perkawinan Jarak Jauh dalam Proses Penyelesaian Konflik Rumah Tangga." Melalui pendekatan kualitatif metode fenomenologi data diperoleh dari in-depth interview terhadap 3 pasangan suami isteri pelaku perkawinan jarak jauh. Hasil penelitian menunjukkan bahwa dialektika konflik diantara pasangan perkawinan jarak jauh terjadi cukup bervariasi. Kemudian pengalaman komunikasi dalam proses penyelesaian konflik, strategi yang digunakan oleh pasangan perkawinan jarak jauh adalah manajemen konflik efektif maupun tidak efektif (Irawati et al., 2013). Penelitian ini berfokus pada ketiga tegangan dialektika dari RDT (Relational Dialectic Theory). Namun dalam hal penyelesaikan konflik penelitian ini tidak menggunakan strategi dialektika relasional. Meskipun pendekatan, teori dan subjek yang digunakan kurang lebih sama dengan penelitian kali ini, tetapi fenomena komunikasi dan metode yang digunakan berbeda.

Selanjutnya, menurut data yang diterima Pengadilan Agama khususnya bulan Juni dan Juli 2020 terjadi peningkatan jumlah perceraian mencapari 57 ribu kasus dengan 80\% adalah kasus gugatan cerai (Halidi, 2020). “Kepala Dinas Pemberdayaan Perempuan, Perlindungan Anak dan Kependudukan Jawa Timur Andriyanto mengakui kasus perceraian di Jatim menunjukkan tren fantastis. Berdasarkan data dari pengadilan agama tahun 2019, tercatat 8.303 kasus. Data hingga September 2020 sudah ada 55.747 kasus" (Wijayanto, 2020).

Karena itu, tipe keluarga pada penelitian kali ini adalah pasangan pernikahan, yaitu dua orang dewasa yang tinggal bersama dalam romantic relationship. Komunikasi pasangan berakar pada rutinitas sehari-hari dan penyelesaian konflik. Mary Anne Fitzpatrick's (1977) seorang perintis dari tipe pasangan berfokus pada bagaimana orang berpikir tentang hubungan pernikahan. la menemukan tiga dimensi yang mendasari ideologi perkawinan (Turner \& West, 2018).

Pertama, konvensionalitas yaitu seberapa besar seseorang menganut peran seks, rutinitas regular serta makna dan fungsi tradisional dari pernikahan. Kedua, ketergantungan yaitu berkaitan dengan seberapa besar ruang, fisik dan psikologis dirasa pasangan cukup atau terpenuhi dalam pernikahan. Terakhir, komunikasi yang mengukur seberapa banyak interaksi konfliktual mendefinisikan pernikahan bagi pasangan. Artinya seberapa pasangan percaya konflik itu adalah hal yang penting atau harus dihindari dalam pernikahan (Turner \& West, 2018).

Teori utama penelitian ini adalah Dialektika yang merupakan proses perjuangan antara makna yang muncul diberbagai wacana yang tidak konsisten. RDT sendiri berfokus pada interaksi tertentu yang dijalani seseorang dengan orang lain tentang kontradiksi yang bersaing dan berperan ketika kita mencoba mengelola kontradiksi tersebut (Stephen W. Littlejohn et al., 2017). Kontradiksi sendiri didefinisikan sebagai dua atau lebih kekuatan 
yang saling bergantung satu sama lain. Pada waktu yang sama keduanya berfungsi untuk meniadakan atau menentang satu sama lain (Erbert, 2000).

Berikut ini adalah definisi dari dialektika relasional menurut pakar ahli. Leslie Baxter menyatakan bahwa teori dialektika adalah mengenai kesatuan dan perbedaan dalam hubungan (Baxter, 1990). la juga menjelaskan, "Konsep inti dalam perspektif dialektis, bagaimanapun juga, adalah kontradiksi, yaitu satu kesatuan yang berlawanan" (Baxter, 2004).

Teori RDT sendiri berfokus pada tiga dialectical tensions. Pertama, autonomy-connection yaitu keinginan simultan untuk mandiri dari keluarga sekaligus untuk mendekatkan diri (keintiman) dengan mereka (Turner \& West, 2018). Baxter menjelaskan, autonomy-connection adalah tegangan yang paling sentral dari dua ketegangan lainnya. Hubungan tidak akan terbentuk kecuali anggota keluarga meninggalkan atau melepaskan individual autonomy. Tetapi, koneksi yang berlebihan justru merusak hubungan karena hilangnya entitas individu. Sebaliknya terlalu banyak autonomy juga merusak identitas individu karena koneksi dengan orang lain adalah hal yang penting bagi pembentukan dan pemeliharaan identitas (West \& Turner, 2009)

Kedua, openness-closedness yaitu keinginan yang bertentangan antara terbuka dan rentan (mengungkapkan informasi pada keluarga) dengan menjadi strategis dan protektif dalam komunikasi (Turner \& West, 2018). Baxter mengidentifikasi openness-closedness sebagai kontradiksi dialektika signifikan kedua yang dialami dalam suatu hubungan. Di satu sisi, pengungkapan terbuka antara pihak-pihak yang berhubungan adalah syarat yang diperlukan untuk keintiman. Namun di sisi lain keterbukaan menciptakan kerentanan bagi diri sendiri, orang lain dan hubungan yang membutuhkan ketertutupan informasi (Baxter, 1990).

Terakhir, novelty-predictability yaitu konflik antara kenyamanan-stabilitas atau kegairahan akan perubahan. Dorongan dan tarikan yang diwakili oleh dialektika tersebut yang membangun kehidupan keluarga. Karena itu, sudah menjadi salah satu tugas utama keluarga dalam komunikasi adalah mengelolanya (Turner \& West, 2018). Baik novelty maupun predictability keduanya dibutuhkan dalam hubungan. Tetapi predictability berlebihan akan menuju pada kondisi disfungsional yang dikenal sebagai "schismogenesis" yang dapat dihasilkan dari interaksi yang terlalu kaku (dapat diprediksi). Terlebih lagi pengulangan yang berlebihan dapat mengakibatkan kematian emosional (Baxter, 1990).

Menurut Baxter (1990) terdapat empat strategi respon utama untuk mengelola tegangan dialektika. Pertama, Cyclic Alteration memilih salah satu dari kutub yang berlawanan secara bergantian. Kedua, Selection yaitu membuat salah satu kutub menjadi lebih dominan. Ketiga, Segmentation memisahkan dan melihat dua kutub sebagai hal yang berbeda. Terakhir, Integration dengan menyatukan dua hal yang berlawanan, dapat terjadi dalam tiga bentuk (West \& Turner, 2009).

Bentuk pertama, Neutralization (menetralisasi) dengan melemahkan intensitas dari kutub yang kontras melalui kompromi antara dua kutub. Bentuk kedua, Reframing (membingkai ulang), yaitu mentransformasikan persepsi dari elemen yang ada agar kontradiksi tidak dilihat sebagai hal yang berlawanan. Mereka melihat kedua kutub berlawanan sebagai suatu peningkatan. Bentuk terakhir, Disqualifying (mendiskualifikasi) yaitu memilih salah satu kutub sebagai pola umum tetapi berlaku pengecualian untuk kasus tertentu.

Melihat fenomena di masa Pandemi Covid-19 menyebabkan pasangan suami isteri semakin sering bertemu hingga meningkatkan tegangan dialektika. Bila dialektika relasional tersebut tidak dikomunikasikan maka dapat merusak hubungan antar pasangan yang mempengaruhi masa depan anak. Karena itu, peneliti ingin mendalami strategi dialektika relasional kedua pasangan dalam masa pandemi Covid-19. Agar dapat menjelaskan bagaimana mereka mempertahankan keharmonisan antar pasangan di masa WFH maupun WFO. Terlebih lagi meskipun menjalani situasi masa pandemi yang sama namun masing-masing pasangan memiliki kondisi yang berbeda membuat peneliti terdorong untuk membandingkan keduanya.

Pasangan pertama keduanya mengalami masa WFH, menikah di usia 30 ke atas dan memiliki dua anak perempuan yang masih kecil. Anak pertama kelas 1 SD dan anak kedua kelas PG yang saat ini menjalani sekolah online. Baik RA-HP harus bekerja, mengurus anak sekaligus melakukan pekerjaan rumah tanpa bantuan asisten rumah tangga. Sebaliknya pasangan kedua sang suami telah kembali bekerja dan isteri adalah ibu rumah tangga. Mereka menikah di masa muda dan memiliki seorang anak laki kelas 1 SD dan seorang anak perempuan yang masih berusia 1,5 tahun. Kesibukan VJ-MC bertambah namun mereka masih mendapat bantuan dari pekerja rumah tangga.

Peneliti juga mengkaji penelitian terdahulu yang serupa sebagai referensi penelitian ini. Penelitian pertama ditulis oleh Angela dan Stella pada tahun 2014 dari California State University yang berjudul "Relational Dialectics and Management Strategies in Marital Couples." Jurnal tersebut meneliti kontradiksi dialektis dalam pernikahan dan mengidentifikasi strategi komunikasi yang digunakan untuk mengelola ketegangan dialektis. Penelitian tersebut adalah penelitian kualitatif dengan metode wawancara semi-terstruktur yang terpisah antara suami dan istri. Penelitian ini berfokus pada tegangan dialektika autonomy-connection dan opennessclosedness. Strategi komunikasi yang digunakan untuk mengelola tegangan autonomy-connection adalah 
segmentasi aktivitas, segmentasi waktu, reframing, iklim interaksi, kompromi, dan seleksi eksklusif. Strategi komunikasi yang digunakan untuk mengelola dialektika openness-closedness adalah pergantian topik, pergantian waktu, penarikan diri, probing, perilaku antisosial, dan penipuan. Berbeda dengan penelitian kali ini, penelitian tersebut hanya meneliti dua dari tiga tegangan dialektika. Kemudian kriteria pasangan suami isteri yang diwawancara telah menikah di bawah 5 tahun serta belum memiliki anak. Kriteria tersebut berkebalikan dengan penelitian kali ini. Selain itu penelitian ini dipengaruhi perubahan lingkungan yaitu di masa pandemi Covid-19 berbeda dengan penelitian tersebut yang tidak bergantung pada kondisi lingkungan (Hoppe-Nagao \& Ting-Toomey, 2002).

Penelitian terdahulu terakhir yang digunakan sebagai acuan maupun referensi ditulis oleh Mthobeli Ngcongo dari University of Johannesburg dengan judul "Mobile communication privacy management in romantic relationships: a dialectical approach" pada tahun 2016. Studi tersebut menyelidiki aturan penggunaan ponsel yang dinegosiasikan oleh remaja dan dewasa muda dalam hubungan romantis. Temuan dari wawancara mendalam menunjukkan bahwa negosiasi aturan adalah bagian penting dari hubungan dewasa muda. Meningkatkan kepercayaan dan menumbuhkan kerukunan adalah faktor penting dalam proses pengembangan aturan. Implikasi, keterbatasan, dan kemungkinan masa depan untuk penelitian dibahas (Ngcongo, 2016). Perbedaan dengan penelitian kali ini adalah fokus pada aturan seputar manajemen privasi seluler dari pada dialektika serta tidak membahas konflik di dalamnya. Penelitian ini hanya menggunakan konsep dasar dari RDT yaitu kontradiksi terutama antara openness dan closedness. Namun untuk analisis dan pembahasan berfokus pada teori Communication Privacy Management. Karena itu, teori yang digunakan berbeda. Selain itu subjek penelitian adalah pasangan remaja dan dewasa muda yang belum tentu sudah menikah.

Pendekatan yang digunakan peneliti dalam mendeskripsikan dan menjelaskan fenomena kali ini adalah pendekatan kualitatif dengan metode studi kasus. Penelitian kualitatif adalah penelitian yang membantu untuk memahami dan menjelaskan makna fenomena sosial. Kemudian penelitian deskriptif merupakan penelitian yang diarahkan untuk memaparkan gejala-gejala, fakta-fakta, atau kejadian-kejadian secara sistematis dan akurat (Wagiran, 2013). Jenis penelitian deskriptif dengan pendekatan kualitatif ini dilakukan untuk memperoleh gambaran mendalam mengenai dialektika relasional pasangan suami isteri di masa pandangan Covid-19. Metode studi kasus sendiri merupakan penyelidikan empiris yang menyelidiki fenomena kontemporer secara mendalam dan dalam konteks kehidupan nyata, ketika batas-batas antara fenomena dan konteks tidak jelas terlihat. Tugas peneliti adalah mengklarifikasikan secara tepat sesuai dengan pertanyaan peneliti sendiri (Ridder, 2012).

Jadi strategi dialektika relasional mana yang diterapkan untuk mengatasi tegangan dialektika oleh kedua pasangan yang berbeda kondisi (WFH dan WFO) namun di masa pandemi Covid-19 yang sama?

\section{METODE}

Sebagai penelitian yang membantu untuk memahami dan menjelaskan makna fenomena sosial, penelitian kualitatif menjadi upaya untuk memahami situasi dalam keunikan mereka sebagai bagian dari konteks tertentu dan interaksi di sana (Aminah \& Roikan, 2019). Kemudian penelitian deskriptif diarahkan untuk memaparkan gejala-gejala, fakta-fakta, atau kejadian-kejadian secara sistematis dan akurat (Wagiran, 2013).

Penelitian ini menggunakan pendekatan kualitatif-deskriptif karena menonjolkan proses bagaimana fenomena sosial dapat terjadi dan makna yang diperoleh. Hal itu dilakukan dengan teori dialektika relasional sebagai dasar panduan yang memperlihatkan strategi pasutri (fokus penelitian) dalam menghadapi pandemi Covid-19 yang menyebabkan kontradiksi meningkat (fakta dan fenomena sosial). Melalui pendekatan tersebut peneliti dapat memperoleh gambaran mendalam mengenai strategi dialektika relasional pasutri di masa pandemi Covid-19.

Teknik pemilihan informan pada penelitian ini dilakukan secara spesifik yaitu memilih narasumber dengan pertimbangan atau memiliki alasan tertentu. Narasumber dipilih berdasarkan fenomena sosial, tujuan penelitian dan sesuai kebutuhan agar dapat menjawab permasalahan dari penelitian. Peneliti memilih narasumber yang merupakan pasangan suami isteri yang memiliki dua anak berusia PAUD. Pasangan yang pertama RA-HP yang mengalami WFH sedangkan pasangan kedua yaitu VJ-MC suaminya telah menjalani WFO.

Peneliti memilih kedua pasangan tersebut karena keduanya merupakan subyek penelitian yang menarik untuk diteliti. Hal itu dilihat dari kondisi pandemi yang menyebabkan pasutri bertemu hampir selama 24 jam. Kemudian meningkatkan kontradiksi maupun konflik batin secara intens ditambah dengan memenuhi kewajiban mendampingi sekolah online, pekerjaan maupun urusan rumah tangga. Terlebih lagi kedua pasangan meskipun sama-sama mengalami pandemi Covid-19 Tetapi memiliki perbedaan situasi yang signifikan antara WFH dengan WFO. 
Terlebih lagi Pasangan RA-HP yang keduanya bekerja masih mengalami WFH sebaliknya pasangan VJ-MC sang suami telah WFO dan sang isteri adalah ibu rumah tangga. Perbedaan besar namun ketegangan antara kedua pasutri sama-sama meningkat drastis. Kemudian kedua pasangan masing-masing memiliki dua anak usia PAUD. Hal itu membuat peneliti ingin menjelaskan dan mendeskripsikan perbedaan strategi dialektika relasional yang terjadi antara pasangan suami isteri tersebut di masa Pandemi Covid-19 yang sama.

Metode yang digunakan adalah metode studi kasus yaitu mencari kedalaman penjelasan atas kasus yang diteliti. Menurut Creswell studi kasus adalah sebuah model yang memfokuskan eksplorasi "sistem terbatas" atas satu kasus khusus ataupun pada sebagian kasus secara terperinci dengan penggalian data secara mendalam (Creswell, 2015). Penelitian ini menggunakan metode studi kasus karena didasari dengan fenomena sosial yang telah terjadi pada pasutri selama pandemi dimana kontradiksi meningkat. Kemudian, peneliti tertarik untuk mempelajari bagaimana kontradiksi yang menyebabkan tegangan dialektika dapat terjadi selama pandemi dan strategi pasutri dalam menangani tegangan tersebut.

Studi kasus menurut Yin, R. K. adalah penyelidikan empiris yang menyelidiki fenomena kontemporer secara mendalam dan dalam konteks kehidupan nyata. Peneliti bertugas mengklarifikasikan secara tepat sesuai dengan pertanyaan dari peneliti sendiri (Ridder, 2012). Meneliti fenomena secara mendalam dapat peneliti lakukan melalui observasi dan wawancara yang merupakan teknik pengumpulan data pada penelitian ini.

Observasi dilakukan saat peneliti mengamati pengakuan informan yaitu ketika pasangan RA-HP dan VJ-MC saling memberitahukan informasi pribadi masing-masing. Pengamatan juga dilakukan saat peneliti melakukan pendekatan hubungan dengan kedua informan. Baik secara online melalui media google meet maupun secara offline dengan berkunjung ke rumah narasumber. Selain itu pengamatan terus dilakukan ketika peneliti melaksanakan wawancara (online dan offline), saat bertemu dengan informan hingga penelitian berakhir.

Peneliti tidak hanya melakukan observasi ketika wawancara namun memutuskan untuk tetap mengunjungi rumah kedua pasangan RA-HP dan VJ-MC agar dapat memperoleh gambaran nyata dan informasi lengkap dari apa yang terjadi. Melalui observasi tersebut peneliti mendapati hal-hal yang mendukung serta memperjelas wawancara yang telah dilaksanakan peneliti. Selain itu terdapat temuan baru yang mungkin terlewat atau tidak terpikir untuk disebutkan ketika wawancara.

Kemudian wawancara mendalam adalah metode yang memungkinkan pewawancara untuk bertanya kepada responden dengan harapan untuk memperoleh informasi mengenai fenomena yang ingin diteliti. Wawancara mendalam dilihat oleh peneliti sebagai kolaborasi antara pewawancara dan partisipan. Artinya hal yang dibahas dan didiskusikan oleh partisipan sama pentingnya dengan apa yang didiskusikan pewawancara. Peneliti ingin mencari tahu pengalaman responden serta memperoleh data dan gambaran yang mendalam dari pada mengumpulkan informasi dari narasumber (West \& Turner, 2009).

Wawancara pada penelitian kali ini akan dilakukan baik secara online melalui media google meet maupun offline dengan cara berkunjung ke rumah narasumber. Melalui wawancara peneliti dapat memperoleh informasi detil yang tidak dapat dilihat langsung oleh peneliti Ketika observasi. Seperti hal-hal yang terjadi di masa lalu, pengalaman masing-masing pribadi maupun sebagai keluarga, pikiran serta perasaan yang tidak diungkapkan secara langsung, pola pikir yang dipegang pribadi maupun bersama dan sebagainya.Melalui observasi dan wawancara peneliti dapat memperoleh informasi lengkap dan mendalam untuk menjawab persoalan dalam penelitian.

Sumber data terbagi menjadi dua yaitu primer dan sekunder. Sumber data primer adalah sumber pertama yaitu sebuah data dihasilkan. Dalam penelitian ini sumber data primer adalah pasangan suami isteri di masa pandemi Covid-19. Data primer yang digunakan dalam penelitian ini diperoleh melalui wawancara mendalam (in-depth interview) untuk memperoleh penjelasan yang lebih luas mengeni berbagai hal yang berkaitan dengan penelitian ini.

Sumber data sekunder adalah data yang diperoleh dari data tertulis seperti sumber buku, jurnal, arsip, website, berita online dan dokumen resmi yang berkaitan dengan fenomena dan teori serta dijadikan acuan peneliti dalam melakukan penelitian. Sebagai data sekunder, penulis akan menggunakan data pendukung dan mengamati keseharian informan serta informasi dari narasumber. 


\section{HASIL DAN DISKUSI}

\section{Perbedaan Tegangan dan Strategi Dialektika Relasional Bergantung Usia dan Karakter Anak}

Usia dan karakter anak telah mempengaruhi dialektika relasional pasangan di masa pandemi. Terlihat dari penjelasan yang dijelaskan oleh masing-masing pasangan. RA menjelaskan bagaimana kedua anaknya sudah dalam usia yang bisa diajari dan dilatih untuk mandiri baik dalam hal bermain, sekolah online maupun pekerjaan rumah tangga. Sebaliknya pasangan VJ-MC pada JS yang berusia satu setengah tahun masih belum dapat diajari untuk memahami situasi dan kondisi yang ada. Kemudian terhadap JY putra pertamanya VJ masih merasa baikbaik saja karena sudah bisa mengerti dan masih bisa bermain sendiri meskipun tidak dalam waktu lama.

Terlihat dari penjelasan yang dijelaskan oleh masing-masing pasangan. RA menjelaskan bagaimana kedua anaknya sudah dalam usia yang bisa diajari dan dilatih untuk mandiri baik dalam hal bermain, sekolah online maupun pekerjaan rumah tangga. "Dua bulanan rasanya masih dibantu-dibantu lama-lama bisa sendiri ya kutinggal. Jadi yang kamu lihat sekarang ini itu adalah hasilnya" jelas RA.

Kemudian dalam menemani anak sekolah maupun bermain mereka terbiasa bergantian. Biasanya HP bekerja dari pagi hingga siang kemudian RA bekerja pada sore hingga malam dan dapat terjadi sebaliknya. Menurut Holmes et. al. (2013) pasangan yang keduanya bekerja harus mengembangkan cara untuk mengelola pekerjaan seperti menerima jasa penitipan anak atau mengembangkan jam kerja baru. Contohnya, seseorang bekerja di siang hari dan pasangannya bekerja di malam hari. Persis sesuai contoh tersebut yang menjadi solusi bagi RA-HP, mereka mengatur jadwal agar tidak bertabrakan dapat bergantian menjaga anak (Galvin et al., 2018).

Sebaliknya pasangan VJ-MC mengalami hal yang jauh berbeda dengan kedua anak anak mereka. VJ menjelaskan mengenai JS, "Ya ya umur segitu ya kayak bukan ngetes ya tapi memang masa-masane masa de e pengen apa-apa pengen terus harus dikasik nek ndak dikasik nangis." (Ya pada seusia JS bukan menguji tapi memang sedang di masa dia ingin banyak hal dan harus diberikan kalau tidak nanti menangis).

Karena itu, untuk anak berusia satu setengah tahun masih belum dapat diajari untuk memahami situasi dan kondisi yang ada. Kemudian terhadap JY putra pertamanya VJ masih merasa baik-baik saja karena sudah bisa mengerti dan masih bisa bermain sendiri meskipun tidak dalam waktu lama. JY sendiri suka melihat ayahnya membetulkan sesuatu dan ingin ikut serta karena sudah cukup besar maka MC berani membiarkannya bersama VJ. Namun mau tidak mau MC tetap ikut bersama menjaga JS terutama yang masih terlalu kecil dan belum mengerti bahaya.

MC juga mengalami kesulitan yang sama karena JY masih TK (belum bisa membaca) maka dari itu MC harus benar-benar mendampingi ketika sekolah online. Bahkan JY sendiri yang meminta MC untuk selalu berada di sampingnya. Akhirnya tidak ada waktu lagi untuk mengurusi JS, "Soale nek gak ada pandemikan pasti isa maksude ada waktu dimana isa ngasi perhatian dia tok (JY) ada waktu dimana isa ngasi perhatian JS tok" (Soalnya kalau tidak ada pandemi pasti masih ada waktu khusus untuk memberikan perhatian JY dan ada waktu bisa memberikan perhatian pada JS saja).

Apa yang terjadi pada MC tepat seperti apa yang Kathleen M. Galvin et. al. (2018) sebutkan. Mereka menjelaskan bertambahnya anak membatasi jumlah waktu dan kontak bagi setiap anak dengan orang tua serta orang tua dengan satu sama lain MC sendiri menceritakan bahwa sebenarnya JS bila tidak bersama JY jauh lebih tenang. Tetapi JS masih di usia meniru semua kelakuan kakaknya bahkah menginginkan apa yang JY punya. Karena itu JS semakin tidak bisa diam bila bersama JY (Galvin et al., 2018).

Tak hanya mengenai usia namun berkaitan pula dengan karakter dari masing-masing anak yang mempengaruhi dialektika relasional pasangan di masa pandemi. Bagi RA yang non-stop bersama anak selama WFH tidak menjadi masalah karena kedua anaknya adalah tipe yang dapat menikmati berada di rumah. Baik $A Y$ dan AF dapat bertahan bermain di rumah terlebih lagi AF justru lebih dapat bermain sendiri. AY sendiri waktunya banyak habis di sekolah setelah itu dapat bermain bersama adiknya. Terlebih lagi keduanya juga dapat membantu pekerjaan rumah tangga seperti mencuci piring dan sebagainya. Ketika RA melakukan hobi pertukangan AY dan AF juga tertarik untuk ikut membuat dan mencoba.

Sejalan dengan sang suami HP juga menjelaskan bagaimana AY dan AF masih suka mewarnai. Terlihat pula ketika observasi bahwa kedua anak tersebut suka beraktivitas dan berkreasi menggunakan tangan seperti art and crafts. AY menggunting kertas sedangkan AF bermain mainan sejenis puzzle. Terdapat pula mainan seperti Lego yang cukup rumit dan perlu disusun dengan panduan namun AY menikmatinya. HP menyebutkan bagaimana kedua anaknya dapat membantu bersih-bersih, menata ranjang sendiri dan mandiri seperti makan dan mandi sendiri. Khususnya AY yang memiliki inisiatif besar namun tetap perlu dijaga agar tidak terjadi bahaya apapun.

Hal yang bertolak belakang terjadi pada VJ-MC melihat kedua anaknya sangat lekat dengan orang tuanya dan selalu ingin ditemani setiap saat. MC juga mengalami kesulitan yang sama karena JY masih TK membuat MC 
harus benar-benar mendampingi ketika sekolah online akhirnya tidak ada waktu lagi untuk mengurusi JS. VJ menekankan, "Kita ngobrol bareng ae gak boleh gitu sangat caper." (kita mengobrol bersama saja tidak boleh, sangat mencari perhatian). Karena itu, MC yang sendirian di rumah ketika VJ bekerja mau tidak mau sangat kewalahan. VJ menjelaskan bagaimana sekolah di rumah membuat beban $\mathrm{MC}$ bertambah terlebih mengajari dan mengerjakan tugas menjadi tanggung jawab tambahan. VJ mengakui bahwa dirinya dan kedua anaknya tidak dapat diam dan selalu ingin keluar rumah. Terlebih lagi baik JY dan JS adalah anak yang banyak bergerak di rumah saja tidak cukup untuk menghabiskan energi mereka dan akhirnya keduanya sering badmood.

Kemandirian dari kedua putri RA-HP tersebut dapat terjadi karena faktor usia mereka. Menurut Maria Montessori (1949) Pada usia 3-6 tahun anak-anak mulai dapat dipengaruhi oleh situasi tertentu. Hal itu ditandai dengan anak yang menjadi lebih individual dan memiliki kecerdasaan yang cukup untuk memasuki sekolah. Karena itu, melalui didikan RA-HP pada masa yang tepat membuat AY dan AF dapat bertanggung jawab dengan baik (Sit, 2015). Berbeda dengan JS yang berusia 1,5 tahun yang terus mencari ayah ibunya serta tidak membiarkan mereka hilang dari pandangannya. Hal itu didukung dengan teori attachment oleh Bowlby (1958) pada fase ketiga yaitu adanya kemelekatan yang intens dan pencarian kedekatan yang aktif pada usia 6 bulan hingga 3 tahun. Pada fase tersebut bayi selalu menangis atau menunjukkan rasa cemas terhadap perpisahan dengan orang tuanya (Sit, 2015).

Dari analisis yang diperoleh peneliti mendapati perbedaan ketegangan antara kedua pasangan dalam hal kedekatan. Pada pasangan RA-HP karena kedua anak mereka telah berada di usia dapat mandiri. Karena itu, baik RA-HP lebih mengarah pada autonomy (menjunjung kemandirian) dengan mengutamakan inisiatif masingmasing pribadi. Namun di sisi lain RA-HP tidak merasa jauh terhadap satu sama lain karena masa WFH membuat mereka selalu bersama.

Sebaliknya pada pasangan VJ-MC karena suami telah kembali bekerja membuat mereka lebih mengutamakan kebersamaan (connection). Selain itu kedua anak mereka juga belum dapat ditinggal sendiri. Hal itu membuat $\mathrm{VJ}$ akan berusaha untuk ikut membantu menjaga anak bersama MC sepulang bekerja. Namun terkadang karena harus terus menerus memperhatikan anak membuat VJ-MC sulit memiliki waktu bersama. Karena itu, mereka berusaha untuk menyediakan waktu khusus agar dapat quality time berdua. Terutama di saat malam hari ketika kedua anak sudah tidur serta ketika jalan-jalan naik motor di sore hari.

Masing-masing pasangan tersebut juga memiliki strategi tersendiri untuk mengatasi tegangan dialektika. Pasangan RA-HP menggunakan strategi cyclic alteration dengan bergantian dan mengandalkan satu sama lain ketika menjaga anak. Strategi kedua adalah bagian dari integrasi yaitu neutralisasi, karena keduanya WFH maka mereka selalu merasa bersama namun sekaligus mandiri dalam kesibukan masing-masing.

Kemudian pasangan VJ-MC juga menggunakan strategi segmentasi. Mereka banyak menghabiskan waktu mandiri karena VJ bekerja dan MC di rumah mengurus anak. Namun mereka menyediakan waktu khusus agar dapat menikmati waktu berdua saja. Terkadang mereka juga melakukan strategi integrasi khususnya reframing yaitu terlihat dari hal-hal yang menjadi me time kesukaan keduanya seperti menonton film justru menjadi waktu bersama.

\section{Profesi Pasangan Menentukan Intensitas Tegangan dan Strategi Dialektika Relasional}

Pada kasus kali ini pasangan RA-HP memiliki pekerjaan yang sama sebagai seorang dosen. Sebaliknya pasangan VJ-MC memiliki pekerjaan yang berbeda. VJ di bidang informatika sedangkan MC di bidang desain interior. RA mengakui melalui pekerjaan yang sama membuat mereka lebih mengerti satu sama lain. Ketika membahas sesuatu juga lebih nyambung bahkan memahami kesibukan satu sama lain.

Seperti kapan perlu sendiri dan kapan perlu bersama serta mengingatkan kegiatan satu sama lain. Keduanya juga menggunakan aplikasi google calendar melalui akun yang sama sehingga dapat mengetahui jadwal satu sama lain tanpa perlu banyak berkomunikasi. HP bahkan menjadi peran penting dalam mengurus bagian administrasi dosen milik RA melihat suaminya tidak terlalu mengurus hal tersebut. Karena itu, HP yang menganggapnya penting membantu mengerjakannya. RA sendiri menyatakan bahwa ia mengobrol dengan HP di luar membahas keluarga adalah mengenai pekerjaan alias gosip.

"Paling gosip, orang ini kayak begini Iho. Apalagi kalau mengikuti seminar yang sama, Wah iya bapaknya aneh hahaha. Ketawa-ketawa sendiri, ya gosip-gosip gitu karena saling kenal."

Sebaliknya berbeda bagi VJ dan MC yang memiliki perbedaan karier. VJ dulunya sangat kesulitan untuk bercerita tentang pekerjaan-nya. la merasa bahwa dunianya jauh berbeda sehingga bila ia ceritakan pun akan percuma. Hal tersebut membuat VJ merasa tidak ada esensi untuk bercerita bila pada akhirnya MC tidak mengerti. Uniknya bila MC menceritakan mengenai pekerjaannya di bidang Desain Interior VJ masih dapat mengerti. Bahkan ketika kuliah VJ yang membantu MC mengerjakan maketnya dan berbagai tugas yang lain. Hal 
tersebut membuat timbulnya jarak hingga terkadang ketika lelah VJ merasa berjuang sendiri sedangkan ia telah mengusahakan banyak bagi isterinya.

Tetapi VJ menyadari bahwa pemikirannya juga tidak sepenuhnya benar dan kembali melihat bahwa MC mensupport dengan cara yang ia dapat lakukan. Terlebih lagi MC yang menginginkan dia cerita agar tidak terjadi kesalahpahaman agar MC dapat memahami kondisi VJ. Bila tidak bercerita maka mudah bagi MC untuk ikut menjadi sensitif atau emosi karena tidak mengerti apa yang sedang dialami sang suami. Akhirnya, VJ selalu berusaha untuk terbuka masalah pekerjaannya terutama setelah ia mengetahui alasan MC memintanya cerita masalah pekerjaan.

"Sebenarnya begini ya karena dia pernah ngomong. Intinya dia selalu merasa ketika mukaku bete itu karena aku marah dengannya. Ya memang jauh lebih baik dia tanya dan aku jawab bukan."

Sebaliknya bila MC terlalu takut membahas hal-hal yang dapat menimbulkan gesekan atau konflik maka ia akan memberanikan diri melalui chat terlebih dahulu. Baru ketika malam hari setelah JY dan JS tidur maka keduanya melakukan konfirmasi dan konsolidasi.

Berlanjut pada sudut pandang MC ia menceritakan bahwa VJ yang dulunya paling tidak suka membahas masalah kantor karena itu akan membuatnya semakin emosi. Tetapi ketika tidak bercerita alias melepaskan emosinya maka VJ justru membuat suasana rumah menjadi suram. Terlebih lagi bagi MC sang suami akan menjadi lebih sensitif mudah dan sering mengomel. Karena itu, agar tidak menimbulkan konflik yang tidak perlu MC memintanya belajar untuk bercerita dan

VJ sendiri bersedia melakukan hal tersebut. Akhirnya sekarang VJ sudah lebih terbiasa untuk bercerita seperti yang diungkapkan oleh MC.

"Iya jadi kadang ya bilang capek karena orang kantor seperti ini. Kadang-kadang tiba-tiba sudah cerita duluan tanpa perlu aku tanya. Kalau dulukan perlu ditanya dulu, ditanya aja belum tentu jawab haha. Sekarang dia berupaya untuk cerita memang harus cerita supaya aku mengerti kondisi dia seperti itu karena apa."

Mengenai pasutri yang memiliki kesamaan pekerjaan berhubungan dengan kepuasan pernikahan dalam penelitian yang dilakukan oleh Gaunt (2006). la menyimpulkan bahwa semakin besar kesamaan atau kemiripan antara pasutri maka semakin tinggi kepuasan pernikahan serta semakin rendah level dari efek negatif. Khususnya kemiripan dari gender personality dan values domains sangat berhubungan kuat dengan kepuasan (Gaunt, 2006).

Kemudian hal yang membuat kedua pasangan tetap harmonis adalah melalui kesepakatan yang menjadi solusi bersama. Sama seperti penelitian yang dijelaskan Agustin dan Hendrati (2013) dengan penjelasan dalam setiap kasus. Pada keluarga dengan isteri bekerja maka isteri harus dapat memanajemen waktu dengan baik dalam melakukan pekerjaan maupun mengurus rumah (Agustin \& Hendrati, 2013). Selain itu tidak lupa meminta bantuan suami bila tidak mampu dan suami sendiri harus dapat menerima dan membantu. RA-HP selalu berinisiatif dalam membantu sama lain dan terbuka bila merasa lelah atau kesulitan. Keduanya tidak melupakan baik kewajiban di rumah maupun tanggung jawab pada pekerjaan masing-masing.

Dari ketegangan tersebut terlihat strategi yang mereka gunakan. Pertama, pasangan RA-HP menggunakan strategi integrasi khususnya disqualifying. Mereka bersepakat untuk selalu terbuka satu sama lain kecuali dalam hal-hal yang mereka kerjakan sendiri keduanya merasa tidak perlu menceritakan kepada satu sama lain. Kedua, pasangan VJ-MC melakukan strategi selection yaitu untuk selalu terbuka dan menceritakan kepada satu sama lain. Meskipun VJ bukan tipe yang banyak terbuka dan sering kali tidak terpikir untuk bercerita. Tetapi, ia berusaha untuk memenuhi keinginan MC serta menyadari kebutuhannya untuk curhat terutama ketika terdapat masalah pada pekerjaan.

\section{Latar Belakang Keluarga Meningkatkan Tegangan Dialektika Antar Pasangan}

Melalui pengalaman masa lalu yang dihabiskan bersama keluarga sering kali menjadi warisan bagi keluarga yang dibangun namun ada pula hal-hal yang ingin diperbaiki. Seperti RA yang dibesarkan oleh pamannya yang sangat tegas dalam melihat akademik sebagai hal yang penting. RA juga melakukan hal yang sama, ia juga sangat tegas bahkan mudah marah masalah pendidikan kepada AY dan AF. Selain itu ketika kecil HP dididik oleh ayahnya dengan diberikan kebebasan mencoba sesuatu hal baru. Karena itu, membuat HP tidak pernah melarang AY dan AF untuk mencoba hal baru dan mencari tau apa yang menjadi kesukaan hingga kemampuan mereka.

Hal yang sama juga terjadi pada pasangan VJ-MC dalam kehidupan keluarganya. Di masa kecil VJ kedua orang tuanya sibuk bekerja berjualan di kantin sehingga tidak banyak waktu mereka habiskan sebagai keluarga. 
Karena itu, VJ tak ingin keluarganya kesepian sehingga ia selalu berusaha untuk meluangkan waktunya bermain bersama kedua anaknya. Kemudian berlanjut pada masa kecil MC, kedua orang tuanya juga terus bekerja namun mereka masih sering menghabiskan waktu bersama di rumah. Mereka jarang pergi keluar kecuali bila ada keperluan hal itu membuat MC sangat terbiasa dan enjoy berada di rumah.

Terdapat beberapa teori yang menjelaskan mengenai bagaimana karakteristik dari keluarga asal terulang pada generasi berikutnya. Pertama, teori Bowenian oleh Bowen (1978) melalui tes konseptualisasi Bowen mengenai transmisi antar generasi. Secara teoritis, proses keluarga yang disfungsional akan mengakibatkan kecemasan pada individu hingga mempengaruhi hubungan romantis selanjutnya (Benson et al., 1993). Terdapat pula multi-generational family theory (1987) oleh Hoopes, bahwa individu memperoleh landasan untuk membangun hubungan dari keluarga asal. Pengaruh multigenerasi ini dapat mengatur keyakinan, sikap, perilaku, harga diri, dan pola interaksional (Topham et al., 2005).

Kedua pasangan melaksanakan strategi yang sama dalam menghadapi ketegangan yang ada terkait latar belakang keluarga asal terutama di masa pandemi. Melalui strategi segmentasi mereka memilih berdasarkan konteks yang ada. Bila terdapat hal positif yang menurut mereka baik untuk diturunkan pada anak mereka maka akan mereka lanjutkan. Sebaliknya bila itu hal yang negatif maka akan dihentikan dan diubah oleh mereka. Kedua pasangan saling terbuka dalam mendiskusikan cara mendidik dan mengasuh agar dapat melakukan yang terbaik bagi keluarga mereka. Hal tersebut sudah menjadi kesepakatan pada kedua pasangan karena mereka melihat keluarga adalah tanggung jawab bersama.

\section{Ketegangan Meningkat Seiring Banyaknya Perbedaan Karakter dan Preferensi Pribadi}

Kedua pasangan masing-masing memiliki perbedaan karakter, pemikiran serta preferensi telah mempengaruhi dialektika relasional mereka di masa pandemi. Dari pasangan RA-HP sendiri mereka lebih sering berdiam dan tidak banyak bicara. Namun perbedaan antara keduanya justru mempererat hubungan mereka di masa WFH. RA yang lebih mudah berempati serta sungkanan dibantu dengan HP yang lebih tegas dan disiplin dalam mengambil keputusan. Sebaliknya RA membantu HP agar lebih fleksibel dan memahami orang lain.

Pada pasangan RA-HP sendiri mereka memiliki prinsip bahwa segala sesuatu bila ada perlu langsung dikomunikasikan sehingga tak ada salah paham. Tetapi pada observasi terlihat mereka jarang sekali berbicara terhadap satu sama lain. Hal tersebut terjadi karena tertutup oleh kemandirian mereka. "Pokoke prinsip kami adalah kalau melihat ada sesuatu yang bisa dikerjakan ya dikerjakan." (Pokoknya prinsip kami adalah bila melihat ada hal yang bisa dikerjakan ya dikerjakan).

Bahkan RA menekankan bahwa mereka tidak banyak membicarakan atau membagi tugas namun berdasarkan kesadaran pribadi. Ketika observasi terlihat pula bagaimana mereka secara otomatis bergantian dan saling membantu ketika salah satu sibuk bekerja. Dalam hal kedekatan antar pasangan keduanya menekankan pada saling memahami dan saling mendukung satu sama lain. Ketika observasi keduanya juga jarang berkonflik melihat masing-masing sama-sama tidak mempermasalahkan hal kecil.

Dalam berkomunikasi antar pasangan mereka hanya mengkomunikasikan hal yang mempengaruhi satu sama lain. Prinsip mereka adalah hal-hal yang dapat mereka putuskan mandiri mereka rasa tidak perlu diceritakan.

"Mandiri seperti misalnya membersihkan rumah misal menyapu itu bisa kulakukan tidak perlu bertanya, 'hari ini nyapu gak ya?' Masak misalnya, 'masak apa hari ini?' Ya itu bisa dipikirkan dan bisa langsung memutuskan sendiri."

Karena itu, pekerjaan rumah dan pekerjaan sebagai dosen tidak banyak mereka ceritakan hingga dalam karena sudah mengerti seperti apa menjadi dosen. Bila mengenai pekerjaan secara detail karena berbeda jurusan maka tidak akan mengerti sehingga tidak mereka ceritakan. Mereka bercerita bila satu sama lain mengenal atau membahas terkait keluarga.

Berbeda dengan pasangan VJ-MC kelebihan dan kekurangan mereka tidak saling melengkapi namun keduanya dapat memahami dan mensupport satu sama lain. VJ dan kedua anaknya suka keluar sayangnya MC adalah seseorang yang menikmati berada di rumah. Karena itu, keduanya terbiasa berkompromi mencari jalan tengah seperti tetap jalan-jalan namun mencari kegiatan yang sederhana.

Dalam hal keterbukaan VJ sendiri lebih suka mendengarkan namun MC juga sebetulnya lebih suka mendengarkan. Tetapi MC tidak suka keheningan antara keduanya terjadi Karena itu, ia terlihat banyak bicara. VJ sendiri berusaha untuk terbuka namun terdapat situasi khusus yaitu ketika ia butuh cerita terutama ketika emosi. Sebaliknya MC justru VJ mengakui ia lebih mudah terbuka ketika melampiaskan emosi namun sering kali MC terkena imbasnya. 


\begin{abstract}
"Jadi seng sering tak jadiin tumpahan emosi itukan MC. Baik dalam bentuk menyakiti maupun tidak menyakiti. Ya pas kejadian e cenderung menyakiti tapi setelah itu kita ngobrol-ngobrol itu aku cerita ya curhat gitu."
\end{abstract}

(Jadi yang sering kujadikan tumpahan emosi adalah MC. Baik dalam bentuk menyakiti maupun tidak menyakiti. Waktu kejadiannya cenderung menyakiti tapi setelah itu kita mengobrol, aku cerita ya curhat gitu)

Karakter dan preferensi tersebut membentuk respon yang unik dalam menghadapi masa pandemi. Pada keluarga RA-HP sendiri yang mengalami WFH selama 24 jam di rumah bersama anak justru lebih menikmati waktu yang ada. Bahkan sang suami menyatakan bagaimana kondisi WFH ini adalah impiannya. RA merasa dapat melakukan banyak hal yang sebelumnya tidak bisa karena waktu telah habis di perjalanan dan sebagainya. Hal yang ia senangi juga di masa pandemi adalah bagaimana ia dapat melihat perkembangan dan sikap anaknya di sekolah.

Bagi sang isteri meskipun HP sebenarnya suka traveling namun ia dengan mudah dapat menerima dan tidak stres. la juga merasa masih bisa berinteraksi dengan orang lain meskipun terbatas. Terlebih ia menikmati pandemi dengan melihat sisi positif yang tidak membuang-buang waktu. Bagi HP yang orangnya disiplin, tegas, tepat waktu maka membuatnya senang dengan efektifitas yang ada.

Sebaliknya, keluarga VJ-MC yang telah kembali bekerja justru jauh lebih tertekan dan tidak menikmati. Meskipun MC sendiri menyukai berada di rumah tetapi 24 jam bersama anak menjadi hal yang tidak mudah baginya. Selain itu, hal yang menjadi kendala adalah karena VJ dan kedua anaknya tidak betah di rumah. Kemudian pandemi yang membatasi mereka untuk jalan-jalan membuat menghadapi anak semakin sulit dan tidak ada istirahat. Sebaliknya ketika sebelum pandemi JY masih sekolah offline justru meringankan beban MC sebagai ibu rumah tangga dan memberinya waktu istirahat dengan hanya menghadapi satu anak.

"Sebenarnya kalau sama anak seperti tidak ada jeda dimana aku bisa cooling down. Tidak ada ruang untuk cooling down, jadi mau tidak mau ya dihadapi. Anak rewel itu seperti terus setiap hari terulang ada aja."

VJ yang tidak betah di rumah sangat sengsara menghadapi kedua anaknya yang tak kenal lelah. la tertekan karena sulit untuk mengajak keluar ke tempat luas yang dapat menghabiskan kedua energi anaknya. la sendiri merasa anaknya jauh lebih mudah untuk cranky di masa pandemi karena terkurung di rumah. Akan tetapi VJ sendiri bersyukur ia telah kembali bekerja karena baginya WFH akan jauh lebih menyiksa. la sendiri memandang pekerjaan sebagai kesempatan untuk bebas dari menjaga anaknya alias escape.

Karakter setiap pasangan sangat mempengaruhi pernikahan bahkan menentukan kepuasan dari masingmasing pasangan hal itu dikatakan oleh Bouchard, Lussier dan Sabourin (1999). Dilanjut oleh Schneewind dan Gerhard (2002) menyebutkan, lebih dari 60 tahun kepribadian telah menjadi fokus utama dari penelitian hubungan pasangan untuk memprediksi dan menjelaskan kualitas serta stabilitas dari hubungan pasutri. Five factor model of personality yang dikemukakan oleh McCrae dan John (1992). Model tersebut didasari lima dimensi dasar yaitu extraversion, agreeableness, lalu conscientiousness, neuroticism, dan openness to experience (Drahman et al., 2018).

Huston dan Houts (1998) menyebutkan bahwa kepribadian dari salah satu pasangan dapat mempengaruhi interaksi pasangan lainnya dalam pernikahan. Hal tersebut dengan jelas terjadi pada kedua pasangan. Kepribadian suami isteri berkaitan dengan perilaku, perasaan dan keyakinan terhadap satu sama lain. Karakter juga berperan dalam seberapa mirip pasangan terhadap satu sama lain. Namun sering kali pasangan tampak lebih mirip dalam hal perilaku dalam sehari-hari dari pada kepribadian itu sendiri (Spotts et al., 2005).

Kedua pasangan menggunakan strategi yang sama yaitu segmentasi. Mereka membuat keputusan berdasarkan konteks yaitu kondisi dan situasi yang ada. Melalui cara tersebut mereka dapat menyesuaikan satu sama lain dengan baik. Terlebih lagi mereka juga tetap dapat melakukan hal yang mereka sukai pada kondisi yang sesuai. Hal itu memperlihatkan bagaimana kedua pasangan saling menyesuaikan satu sama lain dan mengutamakan pasangannya.

\title{
Perlunya Adaptasi dan Alternatif Komunikasi
}

Ketika mendapati situasi masa pandemi tak hanya terjadi respon namun juga adaptasi dalam keluarga agar hubungan tetap harmonis. Pada pasangan RA-HP perubahan terbesar adalah ketiadaan pekerja rumah tangga yang membuat mereka berinisiatif mengerjakan apa yang dapat dikerjakan serta mengkomunikasikan bila lelah maupun tidak dapat melakukan. 
Tidak ada pembagian tugas namun mereka dapat bergantian berbagi beban satu sama lain seperti yang RA jelaskan:

"Kami tidak pernah membicarakan sampai ini bagianmu ini tugasku segala macam."

Meskipun lelah namun RA mengakui kondisi rumah justru menjadi lebih baik ketika tidak ada asisten. RA menjelaskan, "Beda sama waktu dulu, bahkan beda waktu ada pembantu. Jadi ya kok kelihatan rapi ya maksudnya lebih bersih gitu Iho." Selain itu RA dan HP tidak lagi terganggu masalah privasi karena tidak ada lagi asisten yang merupakan orang luar. Kemudian RA bercerita bagaimana anak-anak juga menjadi lebih baik contohnya dapat diajarkan makan di meja makan karena ketika ada asisten mereka masih dibiarkan makan sambil bermain. Bahkan RA merasa bahwa dulu terlalu manja dengan asisten karena tidak perlu memikirkan rumah namun sekarang menjadi lebih mandiri. Selain itu juga menjadi dekat dengan memikirkan satu sama lain terlebih RA-HP berusaha menjadi teladan bagi kedua putri mereka.

Perbedaan kondisi membuat VJ-MC tetap mempekerjakan ART. Hal tersebut mereka lakukan untuk meringankan beban MC ketika ditinggal pergi oleh VJ yang bekerja dari pagi hingga sore. Terutama ketika JY sekolah online MC dapat berfokus menemani tanpa khawatir akan kondisi JS. Selain itu membuat JS tidak menganggu proses belajar mengajar dari JY. Keberadaan asisten rumah tangga menjadi solusi yang tepat bagi kondisi keluarga terutama karena VJ yang telah WFO. VJ sendiri mengakui bahwa masa pandemi justru menjadi lebih berat dan demanding.

"Karena pekerjaan juga jauh lebih banyak maksudnya karena JY sekolahkan di rumah jadi otomatis beban babysitting MC bertambah. Otomatis anak umur segini kalau ada PR yang kerja juga orang tuanya."

RA sendiri berusaha membuat anak-anak tahan berada di rumah dari membuat alat maupun menemani mereka bermain. RA membuat berbagai permainan salah satunya adalah hammock di halaman yang sekarang menjadi tempat favorit bermain kedua putrinya. Selain itu meskipun sibuk bekerja ada saat-saat dimana RA tetap berusaha menemani kedua anaknya.

“Misalnya AF, 'ayok menggambar di sini.' Kasihan karena selasa kamis dia tidak ada sekolah. Jadi diprintkan sesuatu untuk mewarnai. Kadang-kadang ya ditemani bermain tapi sambil kerja."

Berbeda dengan keluarga VJ-MC karena pada dasarnya anak mereka tidak betah berada di rumah. Karena itu mereka membangun kebiasaan baru keluar rumah seperti jalan-jalan di sekitar daerah bermain sepak bola, lari-lari maupun bersepeda di sekitar rumah.

"Makanya kita itu punya kebiasaan sore jalan-jalan naik motor melihat kereta lewat jadi tahu jadwal kereta lewat."

VJ menjelaskan waktu jalan-jalan sore tersebut sekaligus menjadi waktu mengobrol berdua dengan MC. Meskipun dari MC sendiri sebenarnya lebih suka berada di rumah santai-santai tidak melakukan apa-apa. Namun biasanya MC berkompromi kalau keluar mendadak tidak keluar jauh-jauh atau ke tempat yang membutuhkan persiapan. MC menjelaskan, "Jadi misalnya kalau mendadak tapi tidak membutuhkan banyak persiapan masih tidak apa-apa."

VJ juga menekankan ia berusaha menjalani satu kegiatan yang mampu memenuhi lebih dari satu tujuan. Seperti melalui jalan-jalan naik motor di sore hari selain memenuhi kebutuhan anak yang ingin keluar namun juga menjadi waktu ngobrol dengan MC.

Berkebalikan dengan pasangan RA-HP yang menganggap di rumah aja sudah menjadi waktu atau quality time bersama. Mereka juga tidak membutuhkan waktu khusus untuk mengobrol berdua. Karena itu, ketika peneliti melakukan observasi memang keduanya tidak banyak berkomunikasi dengan satu sama lain dan lebih berfokus pada kedua anaknya. Bila memang butuh RA-HP akan mengobrol pada malam hari setelah kedua putri mereka tidur. Sebaliknya pada pasangan VJ-MC mereka benar-benar meluangkan waktu malam hari sebagai waktu komunikasi. VJ merasa keberadaan momen tersebut dibutuhkan agar hubungan antara keduanya baik dan dekat dengan satu sama lain.

Terakhir dalam kondisi pandemi ini baik yang menjalani WFO maupun WFH terdapat perubahan cara me time. Pada RA sendiri ia merasa me timenya semakin banyak dari bekerja, pertukangan, tidur sore, serta waktu di malam hari ketika anak-anak sudah tidur. Pertukangan sendiri terkadang dapat menjadi quality time bersama 
anak-anak. Kemudian HP sendiri juga menganggap bekerja sebagai me time serta waktu di malam hari bila tidak lelah ia akan refreshing dengan mem- browsing resep dan hal-hal yang ia sukai. Weekend bagi RA-HP menjadi waktu istirahat dan dapat melakukan hal-hal yang tidak sempat dilakukan seperti belanja dan bersih-bersih rumah. Hal itu dapat dilakukan karena weekend AY dan AF boleh bermain gadget sehingga mereka menjadi jauh lebih tenang.

Kemudian berlanjut pada pasangan VJ-MC yang suaminya telah WFO. VJ menganggap waktu bekerja adalah masa escape dari keributan bersama anak. Ketika ia lelah bekerja VJ akan berkata pada MC bahwa ia membutuhkan istirahat kemudian tidur di kamar selama kurang lebih $1 \mathrm{jam}$. MC sendiri yang memaklumi kondisi VJ sering kali membiarkan suaminya tidur lebih lama. Bila hanya lelah atau emosi ketika menghadapi anak maka ia akan masuk ke kamar menenangkan diri selama kurang lebih 30 menit. Tetapi VJ mengakui sejak pandemi ia tidak dapat secara efektif menggunakan waktunya. Karena itu, sekarang VJ membangun kebiasaan me time dengan mengikuti komunitas sepeda untuk melepaskan emosinya yang baginya menjadi solusi terbaik di masa pandemi ini.

Mayoritas me time dari VJ dan MC bergabung menjadi waktu quality time berdua. Seperti menonton film atau drama di malam hari setelah kedua anak tidur. Selain itu ketika MC baking terkadang VJ juga ikut menghabiskan waktu bersama. Kecuali membuat clay merupakan pekerjaan sekaligus me time dari MC saja. Sayangnya waktu me time ini bagi MC semakin tidak ada memasuki masa pandemi hanya di malam hari saja bila tidak lelah dan bila pekerjaan rumah telah selesai.

Pada kasus kali ini pandemi dilihat sebagai unpredictable stress yang mempengaruhi kesatuan dan adaptasi keluarga. Terlihat apa yang dilakukan oleh kedua pasangan merupakan upaya mereka menghadapi masa pandemi. Usaha mereka mencerminkan level pertama dari coping strategies yang dikemukakan oleh Burr, Klein dan Associates (1994). Mereka mengubah atau menyesuaikan aturan yang ada, cara melakukan sesuatu dan mengatur kembali tanggung jawab yang ada. Hal itu banyak dilakukan keduanya yang menandakan adanya komunikasi maupun diskusi khusus antara pasangan. Baik itu bernegosiasi, berkompromi, maupun meminta tolong pada satu sama lain (Galvin et al., 2018).

Menurut studi Helms et al. (2014) yang menguji actor-partner interdependence mediation model (APIMeM) membahas mengenai persepsi pasangan akan stres terkait tekanan ekonomi dan adaptasi budaya atau lingkungan. Ditemukan bahwa terdapat hubungan tidak langsung antara stresor adaptasi ekonomi dan budaya serta negativitas terhadap kepuasan pernikahan. Dapat disimpulkan bahwa tekanan psikologis yang muncul pada pasangan terjadi saat menghadapi situasi yang sulit atau beradaptasi dengan lingkungan baru. Dalam penelitian ini situasi sulit dan adaptasi lingkungan baru yang dihadapi pasutri adalah pandemi Covid-19. Baik WFH maupun WFO telah membawa banyak perubahan dan tekanan bagi keluarga. Kemudian kemampuan beradaptasi sendiri tercermin berdasarkan kualitas pernikahan pasutri (Helms et al., 2014).

Strategi yang mereka laksanakan untuk menghadapi perubahan akibat masa pandemi berbeda bagi setiap pasangan. Pasangan RA-HP paling sering melakukan strategi selection dalam hal rutinitas atau menjalani hari. Sebaliknya pasangan VJ-MC melakukan integrasi khususnya neutralisasi untuk membuat perbedaan antar rutinitas dan kegiatan mendadak tidak terlalu jauh berbeda. Mereka berkompromi untuk tetap jalan-jalan namun yang sederhana dan menjadikannya rutinitas baru. Kemudian dalam hal me time keduanya menggunakan strategi segmentasi sesuai konteks yaitu kondisi dan situasi yang ada.

\section{SIMPULAN DAN SARAN}

Berdasarkan penelitian kali ini ditemukan terdapat lima hal yang mempengaruhi dialektika relasional dan strateginya. Pertama usia dan karakter anak, terlihat pasangan RA-HP tidak memiliki masalah karena usia kedua putrinya lebih dewasa. Sebaliknya pasangan VJ-MC lebih mengalami kesulitan karena kedua anaknya terutama putrinya masih kecil. Kedua, kesamaan atau perbedaan pekerjaan juga mempengaruhi relasi kedua pasangan. RA-HP karena pekerjaan yang sama menjadi lebih memahami satu sama lain karena sudah mengerti namun membuat keduanya tidak banyak berkomunikasi. Sebaliknya VJ-MC dengan pekerjaan yang berbeda justru menjadi topik pembicaraan dan membuat keduanya semakin dekat.

Ketiga, latar belakang keluarga yang terbawa hingga saat ini serta ajaran yang mereka ubah. Sering kali tanpa disadari kedua pasangan terbawa kebiasaan negatif dari keluarga asal mereka. Namun hal itu membuat mereka berdiskusi dan sadar akan efeknya terhadap anak mereka. Keempat, Karakter dan preferensi pribadi setiap pasangan membuat mereka menyesuaikan terhadap satu sama lain. Tetapi terdapat pula karakter atau preferensi yang berubah karena terpengaruh oleh pasangan mereka. Terakhir, adaptasi dan alternatif komunikasi terutama di masa pandemi membawa mereka mengubah kebiasaan dan cara mereka. Baik menggunakan sarana lain agar komunikasi lebih efektif atau menyediakan waktu khusus untuk saling berdiskusi. 
Mayoritas strategi yang kedua pasangan gunakan adalah segmentation yaitu dengan memilih salah satu pada konteks tertentu. Seperti VJ yang mengalah dan mengusahakan untuk terbuka kepada MC sehingga seringkali melakukan connection. Kemudian pasangan RA-HP yang saling bergantian menjaga anak dengan mengkomunikasikan kesibukan masing-masing. Namun terkadang mereka juga melakukan integrasi seperti RAHP yang menganggap berada di rumah adalah waktu bersama tidak perlu waktu khusus. Kemudian VJ-MC yang membuat jalan-jalan menjadi kegiatan sederhana seperti keliling naik motor. Melalui strategi yang kedua pasangan lakukan memiliki inti pentingnya komunikasi dengan penuh penyesuaian diri terhadap satu sama lain (dalam pasangan) hingga memperoleh kesepakatan.

\section{REFERENSI}

Agustin, M., \& Hendrati, F. (2013). Hubungan kemandirian istri dengan keharmonisan perkawinan pada tahap awal perkawinan di kelurahan pagentan kecamatan singosari kabupaten malang. Psikologi Tabularasa, $8(2), 691-697$.

Aminah, S., \& Roikan. (2019). Pengantar metode penelitian kualitatif ilmu politik (1st ed.). Prenadamedia Group.

Baxter, L. A. (1990). Dialectical contradictions in relationship development. Journal of Social and Personal Relationships, 7(1), 69-88. https://doi.org/10.1177/0265407590071004

Baxter, L. A. (2004). A tale of two voices: relational dialectics theory. Journal of Family Communication, 4(3), 181-192. https://doi.org/10.1207/s15327698jfc0403\&4_5

Benson, M. J., Larson, J., Wilson, S. M., \& Demo, D. H. (1993). Family of origin influences on late adolescent romantic relationships. Journal of Marriage and the Family, 55(3), 663-672. https://doi.org/10.2307/353347

Creswell, J. W. (2015). Penelitian kualitatif dan desain riset: memilih diantara lima pendekatan. In Penelitian Kualitatif. Pustaka Pelajar.

Drahman, A., Nubailah, S., \& Yusof, M. (2018). The relationship between personality traits and marital satisfaction on quality of marriage among married couples in selangor. International Journal of Humanities, Philosophy and Language, 1(3), 38-47.

Erbert, L. A. (2000). Conflict and dialectics: Perceptions of dialectical contradictions in marital conflict. Journal of Social and Personal Relationships, 17(4-5), 638-659. https://doi.org/10.1177/0265407500174009

Galvin, K. M., Braithwaite, D. O., Schrodt, P., \& Bylund, C. L. (2018). Family communication: Cohesion and change, tenth edition. In Family Communication: Cohesion and Change, Tenth Edition. Routledge. https://doi.org/10.4324/9781315228846

Gaunt, R. (2006). Couple similarity and marital satisfaction: Are similar spouses happier. In Journal of Personality (Vol. 74, Issue 5, pp. 1402-1420). https://doi.org/10.1111/j.1467-6494.2006.00414.x

Halidi, R. (2020, August 31). Penyebab Tingginya Angka Perceraian di Indonesia Saat Pendemi Covid-19. https://www.suara.com/lifestyle/2020/08/31/182022/penyebab-tingginya-angka-perceraian-diindonesia-saat-pendemi-covid-19

Helms, H. M., Supple, A. J., Su, J., Rodriguez, Y., Cavanaugh, A. M., \& Hengstebeck, N. D. (2014). Economic pressure, cultural adaptation stress, and marital quality among mexican-origin couples. Journal of Family Psychology, 28(1), 77-87. https://doi.org/10.1037/a0035738

Herawati, T. (2020, June 29). Peran keluarga menjadi kunci utama di era pandemi Covid-19 dan new normal. Https://Ipb.Ac.Id/News/Index/2020/06/Peran-Keluarga-Menjadi-Kunci-Utama-Di-Era-Pandemi-Covid19-Dan-New-Normal/97065bf36bb764b8257e2b474ab6102f.

Hoppe-Nagao, A., \& Ting-Toomey, S. (2002). Relational dialectics and management strategies in marital couples. Southern Communication Journal, 67(2), 142-159. https://doi.org/10.1080/10417940209373226

Irawati, D., Sunarto, S., \& Rahardjo, T. (2013). Memahami dialektika konflik dan pengalaman komunikasi pasangan perkawinan jarak jauh dalam proses penyelesaian konflik rumah tangga. Interaksi Online, $1(4)$.

Ngcongo, M. (2016). Mobile communication privacy management in romantic relationships: a dialectical approach. Communicatio, 42(1), 56-74. https://doi.org/10.1080/02500167.2016.1140666

Nursastri, S. A. (2020, April 9). Dampak baru Covid-19: meningkatnya angka KDRT di berbagai negara. Https://Www.Kompas.Com/Sains/Read/2020/04/09/120300323/Dampak-Baru-Covid-19-Meningkatnya-Angka-Kdrt-Di-Berbagai-Negara?Page=all.

Petronio, S. (2010). Communication privacy management theory: what do we know about family privacy regulation. Journal of Family Theory \& Review, 2(3), 175-196. https://doi.org/10.1111/j.17562589.2010.00052.x 
Ridder, H.-G. (2012). Yin, Robert K. : case study research design and methods. Zeitschrift Für Personalforschung, 26(1), 93-95.

Sit, M. (2015). Psikologi perkembangan anak usia dini. Perdana Publishing.

Spotts, E. L., Lichtenstein, P., Pedersen, N., Neiderhiser, J. M., Hansson, K., Cederblad, M., \& Reiss, D. (2005). Personality and marital satisfaction: A behavioural genetic analysis. European Journal of Personality, 19(3), 205-227. https://doi.org/10.1002/per.545

Stephen W. Littlejohn, Foss, K. A., \& Oetzel, J. G. (2017). Theories of human communication eleventh edition. In Waveland Press, Inc. (Issue 95). Waveland Press, Inc. https://doi.org/10.1017/CBO9781107415324.004

Sudiana, N. (2020, July 14). Manajemen konflik keluarga amil di masa pandemi Covid-19. Https://Republika.Co.Id/Berita/Qbws3r282/Manajemen-Konflik-Keluarga-Amil-Di-Masa-PandemiCovid19.

Tim. (2020, May 15). Dampak positif negatif pandemi pada hubungan keluarga. Https://Www.Cnnindonesia.Com/Gaya-Hidup/20200514141751-284-503363/Dampak-PositifNegatif-Pandemi-Pada-Hubungan-Keluarga.

Topham, G., Larson, J., \& Holman, T. (2005). Family-of-origin predictors of hostile conflict in early marriage. Contemporary Family Therapy, 27(1), 101-121. https://doi.org/10.1007/s10591-004-1973-2

Turner, L. H., \& West, R. (2018). Perspective on family communication (5th ed.). McGraw Hill Education. Wagiran. (2013). Metodologi penelitian pendidikan: teori dan implementasi. Deepublish.

West, R., \& Turner, L. H. (2009). Pengantar teori komunikasi: analisis dan aplikasi (3rd ed.). Salemba Humanika. Wijayanto. (2020, November 6). Sembilan Bulan Pandemi Corona, Perceraian di Jatim Capai 55.747 Kasus. https://radarsurabaya.jawapos.com/read/2020/11/06/223108/sembilan-bulan-pandemi-coronaperceraian-di-jatim-capai-55747-kasus 